\title{
Anthocyanin concentration and antioxidant activity in light-emitting diode (LED)-treated apples in a greenhouse environmental control system
}

\author{
Pornpan Lekkham ${ }^{1}$, Varit Srilaong ${ }^{1}$, Nutthachai Pongprasert ${ }^{1}$ and Satoru Kondo ${ }^{2, \star}$ \\ 1 School of Bioresources and Technology, King Mongkut's University of Technology Thonburi, Bangkok 10150 Thailand \\ 2 Graduate School of Horticulture, Chiba University, Matsudo, 271-8510 Japan
}

Received 15 September 2015 - Accepted 6 February 2016

\begin{abstract}
Introduction. Anthocyanins are a group of flavonoids, and their synthesis is influenced by external and internal factors such as light, temperature, phytohormones and sugar concentration. A high anthocyanin concentration, which is related to redder coloration, is one of the factors of high-quality fruit. The effects of LED irradiation on the anthocyanin concentration and enzymatic and antioxidant activities in apple skin were studied. Materials and methods. Nine 8-year-old 'Tsugaru' apple trees (Malus domestica Borkh.) grafted onto Malling26 (M.26 EMLA) rootstocks planted in 45-L plastic pots covered with polyvinyl film (90\% transmittance) and grown in a greenhouse were used. The effects of red or blue light-emitting diode (LED) irradiation on anthocyanin accumulation, the expression of $M d$ $M Y B 10$ and UDP-glucose-flavonoid 3-O-glucosyltransferase $(M d U F G T)$ and superoxide anion radical $\left(\mathrm{O}_{2}^{-}\right)$scavenging activity in the skin of 'Tsugaru' apples were investigated under early heating cultivation in a greenhouse. Results and discussion. The anthocyanin concentrations in red LEDtreated apples were increased compared with those of the blue LEDtreated apples and the untreated control at 130 days after full bloom (DAFB). The relative expression of MdMYB10 and MdUFGT genes at 130 DAFB was also highest in the skin of apples treated with red LED light. The skin of apple fruits treated with red or blue LED light showed significantly low $\mathrm{EC}_{50}$ values. Conclusion. These results suggest that red LED irradiation may be used in a controlled environment such as a greenhouse to increase the anthocyanin synthesis and antioxidant activity in apple skin.
\end{abstract}

Keywords: Japan / apple / Malus domestica / light treatment / phenolics / secondary metabolism / fruit quality

Résumé - Concentration en anthocyanes et activité anti-oxydante des pommes traitées aux diodes électroluminescentes (LED) en système de serre à environnement contrôlé. Introduction. Les anthocyanes sont un type de flavonoïdes dont la synthèse est influencée par des facteurs internes et externes tels que la lumière, la température, les phytohormones et la concentration en sucre. Une concentration en anthocyanes élevée, liée à la coloration rouge, est un des critères de grande qualité des fruits. Les effets de l'éclairage LED ont été étudiés sur la concentration en anthocyanes et sur les activités enzymatiques et anti-oxydantes dans la peau de la pomme. Matériel et méthodes. Neuf pommiers âgés de 8 ans (Malus domestica Borkh., cv. Tsugaru) greffés sur 'Malling 26' (M.26 EMLA) et plantés en pots de $45 \mathrm{~L}$ recouverts de film de vinyle (90\% de transmission) ont été cultivés en serre pour cette étude. Les effets d'un éclairage LED rouge ou bleu sur l'accumulation des anthocyanes, l'expression des enzymes MdMYB10 et UDPglucose-flavonoïde 3-O-glucosyltransférase $(M d U F G T)$, et l'activité de piégeage du radical superoxyde $\left(\mathrm{EC}_{50}\right)$ dans la peau des pommes 'Tsugaru' ont été étudiés en culture sous serre au début de la période de chauffage. Résultats et discussion. Les concentrations en anthocyanes des pommes traitées aux LED rouges ont augmenté par rapport à celles des pommes LED traités bleus et du témoin non traité, à 130 jours après pleine floraison (DAFB). L'expression relative des gènes MdMYB10 et MdUFGT à 130 DAFB était également plus élevée dans la peau des pommes traitées aux LED rouges. La peau des pommes traitées aux LED rouges ou bleues a montré des valeurs significativement faibles de l'activité anti-oxydative $\left(\mathrm{EC}_{50}\right)$. Conclusion. L'éclairage aux LED rouges pourrait être utilisé en environnement contrôlé, comme une serre pour augmenter la synthèse des anthocyanes et l'activité anti-oxydante de la peau de la pomme.

Mots clés : Japon / pomme / Malus domestica / traitement / lumineux / composés phénoliques / métabolites secondaires / qualité des fruits

^ Corresponding author: s-kondo@faculty.chiba-u.jp 


\section{Introduction}

It is well known that polyphenols such as anthocyanins in apples (Malus x domestica) are strong antioxidants [1]. Anthocyanins may have health benefits such as protecting against heart disease and colon cancer [2,3], and they may also help improve human visual function [4]. Anthocyanins are a group of flavonoids [5], and their synthesis is influenced by external and internal factors such as light, temperature, and phytohormone and sugar concentrations [6]. A high anthocyanin concentration, which is related to redder coloration is one of the factors of high quality fruit [5].

The anthocyanin in apple skin is primarily cyanidin 3 -galactoside [7]. In apples, light is the strongest factor affecting the anthocyanin accumulation in the skin [8]. The quality and intensity of light affect the anthocyanin concentration in apples [9], and these effects vary among plants [6]. Light-emitting diodes (LEDs) can regulate the distribution of light [11]. The effects of light quality on plant growth in leaf vegetables have been examined $[12,13]$. Red LED treatment was effective in increasing the $\beta$-cryptoxanthin concentrations in satsuma mandarin fruit (Citrus unshiu Marc.) [14]. It has also been shown that grape plants (Vitis spp.) cultured using red LEDs produce the longest shoots with longer internodes, whereas the chlorophyll content is highest in plants cultured using blue LEDs [15].

In one of our earlier studies, we observed that blue or red LED irradiation stimulated sugar synthesis in grape berries, and this may have depended on the promotion of the photosynthesis rate in leaves; our findings also showed that blue LED irradiation stimulated anthocyanin synthesis through $M Y B$ and UFGT genes in grapes [16]. Plant MYBs can regulate secondary metabolites such as anthocyanins, and $M y b A$ influences the production of anthocyanins and $U F G T$, which is one of the structural genes in anthocyanin synthesis [17].

It has been shown that transcription factor genes such as $M d M Y B 10$ are responsible for controlling anthocyanin biosynthesis in apple fruit [18]. MdMYB10 is a gene encoding the biosynthetic enzyme in the anthocyanin pathway in apples [18]. The anthocyanin biosynthesis in apples was inferior under high temperature compared with low temperature [19]. Therefore, the coloration of apples that are grown in a warm area may be improved by regulating the harvest time in a greenhouse environmental control system. However, there is little information about the effects of LED irradiation on anthocyanin accumulation in apples. In the present study we investigated the effects of LED irradiation on the anthocyanin concentration, the expression of MdMYB10 and UDP-glucoseflavonoid 3-O-glucosyltransferase (MdUFGT), sugar concentrations, and antioxidant activity in apple skin under early heating cultivation in a greenhouse.

\section{Materials and methods}

\subsection{Plant materials}

We used nine 8-year-old 'Tsugaru' apple trees (Malus $\times$ domestica Borkh.) grafted onto Malling 26
(M.26 EMLA) rootstocks planted in 45-L plastic pots covered with polyvinyl film (90\% transmittance) and grown in a greenhouse at Chiba University, located at $35^{\circ} \mathrm{N}$ lat., $140^{\circ} \mathrm{E}$ long. and $37 \mathrm{~m}$ alt. The greenhouse was heated to maintain a temperature of $\geqslant 10{ }^{\circ} \mathrm{C}$ by an oil heater throughout the experiment. The heating was started on Jan. 21, and full bloom was Feb. 27. The full bloom in the open field was May 1.

Three test groups of three apple trees each were created. Each tree had approx. 30 fruits. Each plastic pot was watered daily with $20 \mathrm{~L}$ tap water. The trees in the first group were irradiated with red LED light (Shibasaki, Inc., Saitama, Japan; peak wavelength $660 \mathrm{~nm}$ ) for $3 \mathrm{~h}$ before sunrise and $3 \mathrm{~h}$ after sunset (this regimen had a positive effect on the anthocyanin synthesis of grape berries [16]) from 60-142 days after full bloom (DAFB).

The trees in the second group were irradiated with blue LED light (peak wavelength $450 \mathrm{~nm}$ ) on the same schedule. The third group was the untreated control. In each group, each tree was irradiated from the side using eight LEDs (length $147 \mathrm{~cm}$; width $4 \mathrm{~cm}$ ). The photosynthetic photon flux (PPF) of the red and blue LEDs was adjusted to $50 \mu \mathrm{mol} \mathrm{m}^{-2} \mathrm{~s}^{-1}$ at a distance of $10 \mathrm{~cm}$ from the LED. The PPF measured at each fruit was $13-19 \mu \mathrm{mol} \mathrm{m}{ }^{-2} \mathrm{~s}^{-1}$.

Eighteen fruits from each test group (three replications of 6 fruits per tree) were sampled 117, 130 and 142 DAFB for the analysis of anthocyanin, the expression of $M d M Y B 10$ and $M d U F G T$, the values of the $\mathrm{EC}_{50}$ (i.e., the concentration of a drug that gives a half-maximal response), and sugar concentrations. After the skin of the fruit was peeled, the skins were immediately frozen in liquid nitrogen and stored at $-80^{\circ} \mathrm{C}$ until analysis.

\subsection{Anthocyanin analysis}

Anthocyanins were extracted from the apple skin $(0.5 \mathrm{~g}$ fresh weight [FW]; three replications) with $5 \mathrm{~mL}$ of $2 \%$ formic acid and kept at $4{ }^{\circ} \mathrm{C}$ for $24 \mathrm{~h}$ in the dark. The anthocyanin concentrations were analyzed with high-performance liquid chromatography (HPLC) and an HPLC mass spectrometer (model LCMS-2010 EV; Shimadzu, Kyoto, Japan) with a Mightysil RP-18 ODS column according to the method described by Kondo et al. [16] and Wang et al. [20]. Total anthocyanin concentrations are expressed as cyanidin 3-O-galactoside.

\subsection{Sugar analysis}

Skin samples (1 g FW; three replications) in $10 \mathrm{~mL} 80 \%$ (v/v) ethanol were heated at $60{ }^{\circ} \mathrm{C}$ for $10 \mathrm{~min}$ and homogenized after cooling. The homogenate was filtered, evaporated, and analyzed by HPLC (model L-6200; Hitachi, Tokyo, Japan) with a Shodex ODP2 HP-4E column [Showa Denko, Tokyo, Japan; $4.6 \mathrm{~mm}$ i.d. $\times 25 \mathrm{~cm}$ ]. A column at $30{ }^{\circ} \mathrm{C}$ with a flow rate of $1 \mathrm{~mL} \mathrm{~min}^{-1}$ at $75 \%(\mathrm{v} / \mathrm{v})$ acetonitrile and a refractive index (RI) detector were used. 


\subsection{Superoxide anion radical scavenging activity}

A 1-g sample of apple peel was homogenized in $80 \%$ $(\mathrm{v} / \mathrm{v})$ ethanol and filtered. The superoxide anion $\left(\mathrm{O}_{2}^{-}\right)$radicalscavenging activity was measured by the nitrite method [21]. The reaction mixture consisted of $50 \mu \mathrm{L}$ of sample solution, $100 \mu \mathrm{L}$ of a mixture of $65 \mathrm{mM}$ potassium phosphate, $35 \mathrm{mM}$ borax and $0.5 \mathrm{mM}$ EDTA buffer (pH 8.2), $100 \mu \mathrm{L}$ of $0.5 \mathrm{mM}$ hypoxanthine, $50 \mu \mathrm{L}$ of $10 \mathrm{mM}$ hydroxylammonium chloride with $1 \mathrm{mg} \mathrm{mL}^{-1}$ hydroxylamine $O$-sulfonic acid, and $100 \mu \mathrm{L}$ distilled water. One hundred $\mu \mathrm{L}$ of $5 \mathrm{mU} \mathrm{mL}^{-1}$ xanthine oxidase of was added to this mixture.

After incubation at $37{ }^{\circ} \mathrm{C}$ for $30 \mathrm{~min}, 1 \mathrm{~mL}$ of a mixture of $30 \mu \mathrm{M} \mathrm{N}$-(1-naphthyl) ethylenediamine dihydrochloride, $3 \mathrm{mM}$ sulfanilic acid, and $4.2 \mathrm{M}$ glacial acetic acid was added to induce diazo dye formation at $25^{\circ} \mathrm{C}$ for $30 \mathrm{~min}$. Distilled water was added to the blank instead of xanthine oxidase, and $80 \%(\mathrm{v} / \mathrm{v})$ ethanol was used instead of a sample solution as the untreated control. The absorbance at $550 \mathrm{~nm}$ was determined using a U-2910 spectrophotometer (Hitachi, Tokyo). The antioxidant activity [half maximal (50\%) effective concentration $\left.\left(\mathrm{EC}_{50}\right)\right]$ was determined at the mid-point $(50 \%)$ between zero and the full inhibition of diazo dye formation. The $\mathrm{EC}_{50}$ value relates to the weight of the sample (mg dry weight: DW) in $1 \mathrm{~mL}$ of the reaction mixture.

\subsection{RNA extraction, cDNA synthesis, and quantitative real-time RT-PCR analysis}

Total RNA extraction from the skin $(2 \mathrm{~g} \mathrm{FW}$; three replications) was performed as described by Kondo et al. [16]. RNA extraction and cDNA synthesis were performed three times on each sampling date. A quantitative real-time reverse transcription-polymerase chain reaction (RT-PCR) was carried out using KAPA SYBR FAST Master Mix (Kapa Biosystems, Boston, MA) with an Applied Biosystems StepOnePlus RealTime PCR system (Life Technologies, Tokyo) following the manufacturer's instructions.

The following gene-specific primers were used: $(M d-$ MYB 10: forward $\left(5^{\prime}-3^{\prime}\right)$

ACCAATGTGATAAGACCTCAGCCCC; reverse $\left(5^{\prime}-3^{\prime}\right)$

CATTTCCATTCTTTGTTGACGACGA [22], MdUFGT: forward $\left(5^{\prime}-3^{\prime}\right)$

GCCCTTCCAAACACTCTCTTCTC; reverse (5'-3')

CCCGTCAGCCACATCGTACACC) [22].

\subsection{Statistical analysis}

Data are shown as means \pm standard error (SE) of three replications, subjected to analysis of variance (ANOVA) procedures, and separated by the Tukey-Kramer test at $P \leqslant 0.05$ using the SAS statistical analysis package (version 9.0, SAS Institute, Cary, NC, USA).

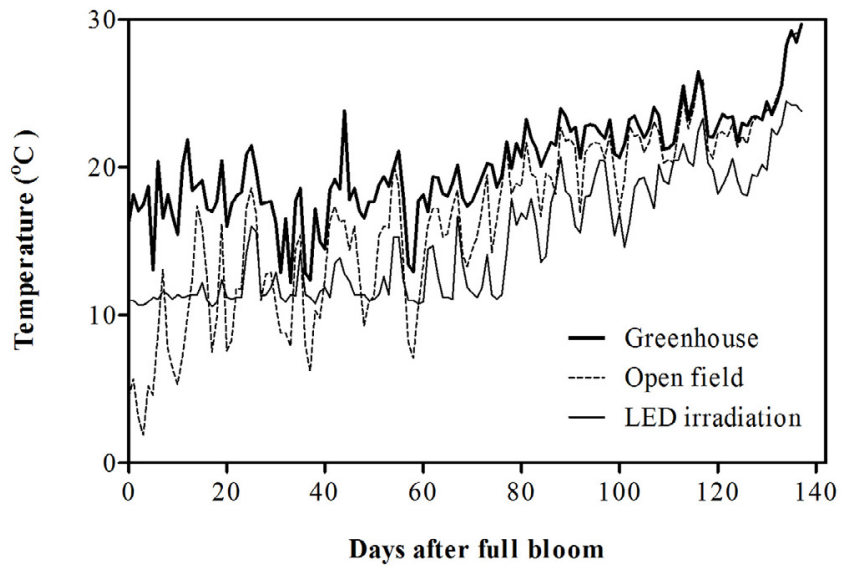

Figure 1. Changes in temperature in the greenhouse covered with polyvinyl at Chiba University. LED irradiation (-) shows the average temperature during LED irradiation.

\section{Results and discussion}

\subsection{Temperature and anthocyanin formation}

The average temperatures from full bloomto 142 DAFB (harvest) are shown in figure 1. The average temperature inthe greenhouse $\left(20.2 \pm 4.6{ }^{\circ} \mathrm{C}\right)$ was approx. $4^{\circ} \mathrm{C}$ higher than that in the open field and theaverage temperature during the LED irradiationwas between 15.1 and $16.7^{\circ} \mathrm{C}$. There were no significant differences in the fruit diameter or length between the red or blue LED groups and the untreated control group (data not shown).

Temperature is an important factor in the synthesis of anthocyanin, and $10-25{ }^{\circ} \mathrm{C}$ is the appropriate temperature for inducing anthocyanin accumulation in 'Tsugaru' apples [19]. In grapes, the low temperature of $20^{\circ} \mathrm{C}$ enhanced anthocyanin accumulation [23]. In contrast, the expression of $C H S, F 3 H$, $D F R, L D O X$, and UFGT in the anthocyanin pathway was downregulated at the high temperature of $35^{\circ} \mathrm{C}$ and anthocyanin concentrations were also decreased in grapes [24]. In light of the results of the present experiment, it appears that the range of temperature in the greenhouse was suitable for anthocyanin formation in apples.

\subsection{Effect of LED irradiation on anthocyanin synthesis and sugar concentrations}

The anthocyanin concentrations in the red LED-treated apples at 130 DAFB were significantly higher than those in the blue LED-treated and untreated control apples (figure 2). The relative expression levels of MdMYB10 and MdUFGT genes in the red LED-treated apples at 130 DAFB were also significantly higher than those in the blue LED-treated and untreated control apples.

The sugar concentrations were not significantly different between the two treatments at 117 and 130 DAFB (data not shown). However, the red LED irradiation increased the glucose concentrations compared with the untreated control, although the differences in the fructose and sucrose 

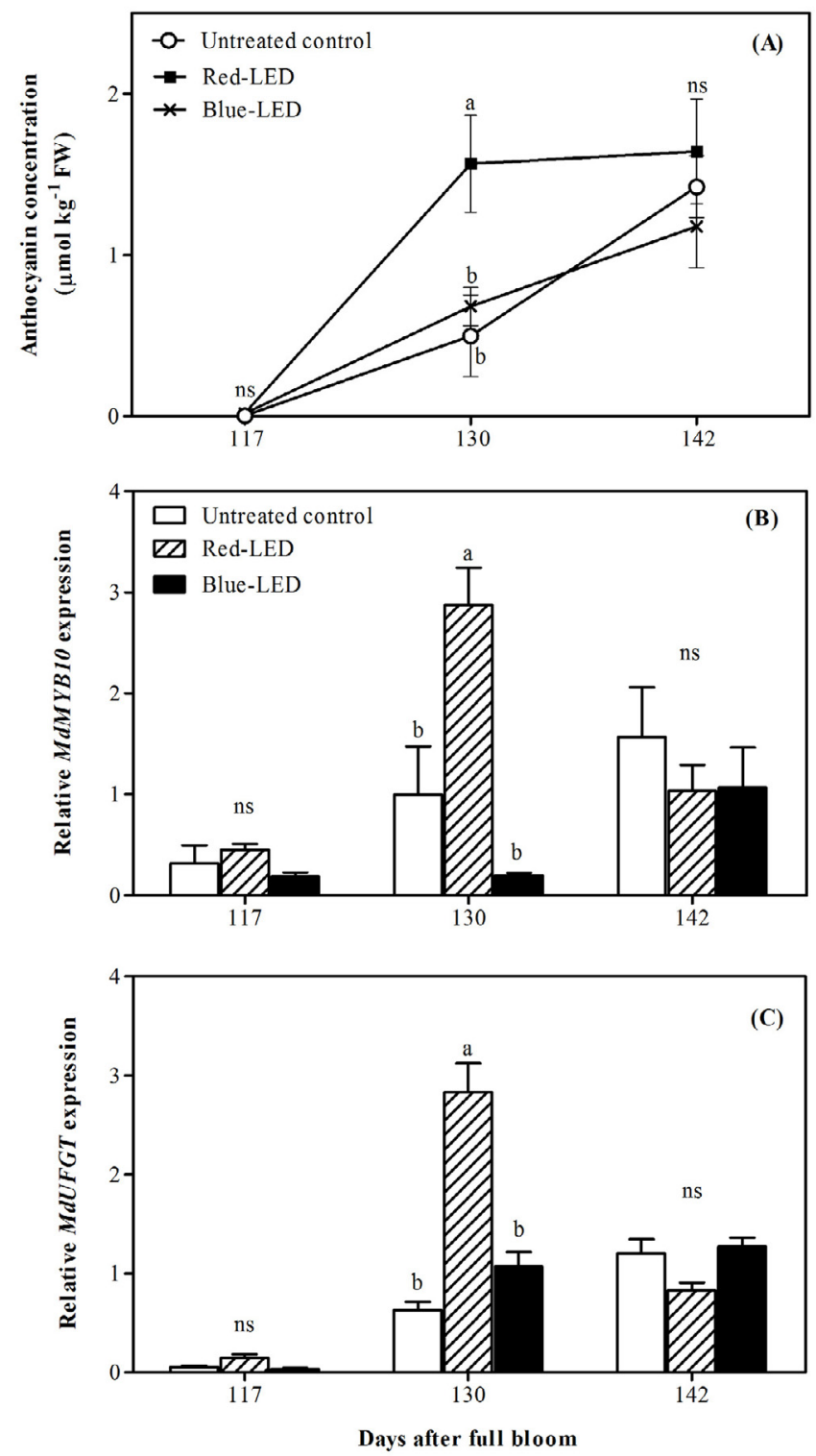

Figure 2. Total anthocyanin concentrations (A) in red or blue LEDtreated apple skin, and quantitative real-time RT-PCR analysis of (B) $M d M Y B 10$ and (C) MdUFGT in apple skins. The experimental values are plotted compared with the control (Ubiquitin) value. Data are the means \pm SE of three replications $(n=8)$. Different letters indicate significant differences by the Tukey-Kramer test at $P \leqslant 0.05$.

concentrations were not significant between the treatments at 142 DAFB (figure 3).

MdMYB10 is a light-inducible MYB transcription factor in apple that regulates anthocyanin biosynthesis in fruit skin [25-27]. Our present findings showed that the expression of $M d M Y B 10$ was upregulated in red LED-treated apple skin. UFGT is also an important enzyme in the development of red pigmentation in apples [26]. In our study, the expression of MdUFGT was also upregulated in the red LED-treated skin, and this coincided with the expression of MdMYB10 and the anthocyanin concentrations. However, the differences in anthocyanin concentrations, as well as the difference in the

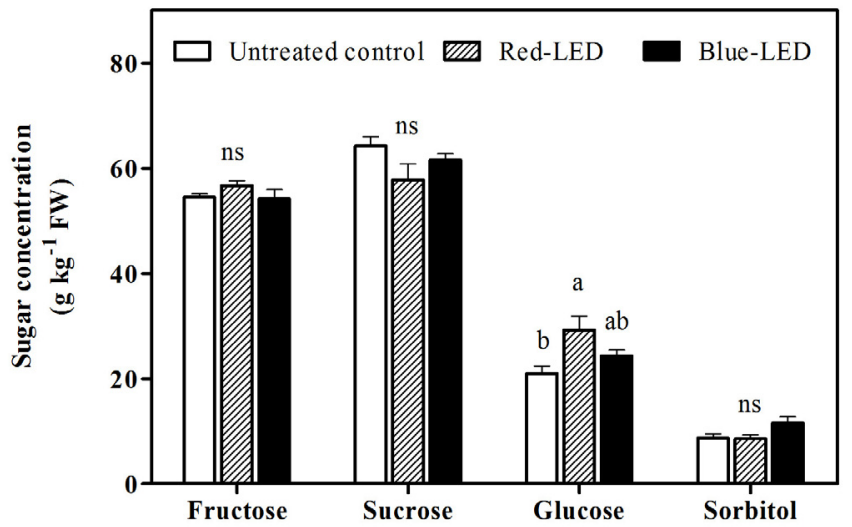

Figure 3. Sugar concentrations in red or blue LED-treated apple skin at 142 DAFB. Data are the means \pm SE of three replications $(n=8)$. Different letters indicate significant differences by the Tukey-Kramer test at $P \leqslant 0.05$.

expression of $M d M Y B 10$ and $M d U F G T$, were not significant between treatments at 142 DAFB (harvest). This suggests that red LED irradiation may advance earlier anthocyanin formation in the skin.

The level of solar irradiation changes with the season. The spectrum changes daily in terms of radiation intensity, but the light quality is more stable [28]. The quality of sunlight may influence plant growth, reproductive growth, and pigmentation in plants [29]. In Japan, the percentage of blue light in sunshine gradually increases toward June (the summer solstice) and decreases toward December (the winter solstice). The percentage of red light shows the opposite tendency [30]; i.e., $30 \%$ blue and $35 \%$ red are observed around the time of the summer solstice and $25 \%$ blue and $40 \%$ red are observed around the time of the winter solstice.

In leaf lettuce, supplementary red LED irradiation during the growing season increased sugar concentrations [31]. A previous report noted that blue LED irradiation was effective in increasing anthocyanin synthesis in lettuce and strawberry (Fragaria $\times$ ananassa Duchesne) [32,33]. In our earlier study of grapes, blue LED irradiation at night was found to be more effective in producing anthocyanins than red LED irradiation [16]. The finding that blue LED irradiation did not stimulate anthocyanin formation suggests that the PPF of blue LED light at night may not be sufficient for anthocyanin accumulation in apples.

Red light is primarily absorbed by phytochromes, whereas blue light is absorbed by cryptochromes and phototropins [34]. The results of our previous study showed that red or blue LED irradiation at night stimulated sugar synthesis in grape berries [14]. Anthocyanin production in grapes was induced through the $\mathrm{F} 3 \mathrm{H}$ protein response in berries in a medium that contained sugar, compared with a medium without sugar [35]. Little or no anthocyanin is produced in apples whose skin is not exposed to direct sunlight, and UV radiation is effective in inducing anthocyanin formation [36]. The present experiment was carried out from February to June, when the ratio of blue light in sunshine gradually increases toward the summer solstice (June) [30]. In our experiment, the red LED irradiation 


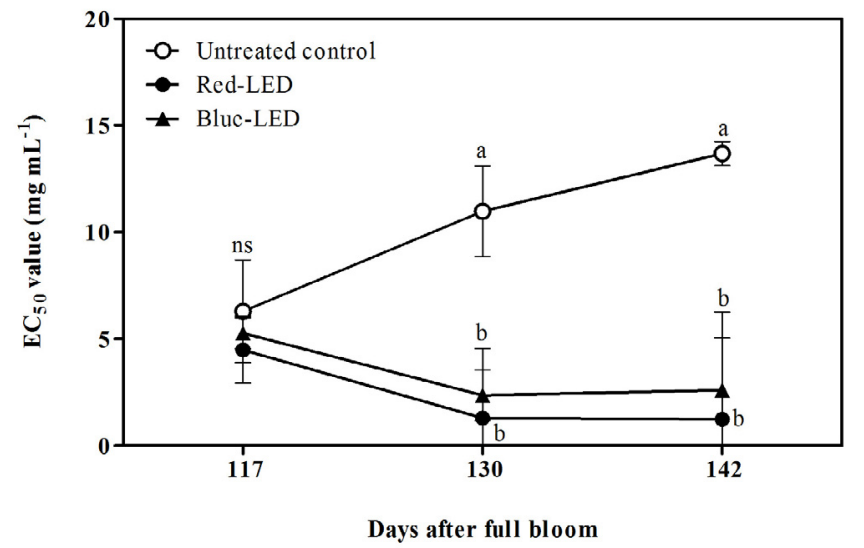

Figure 4. $\mathrm{EC}_{50}$ values of the superoxide anion radical scavenging activity in red or blue LED-treated apple skin. Data are the means \pm SE of three replications $(n=8)$. Different letters indicate significant differences by the Tukey-Kramer test at $P \leqslant 0.05$.

stimulated glucose concentrations. Therefore, it is possible that the blue light in sunshine (the proportion of which increases gradually toward the ripening time of apples) together with the sugar that was increased by red LED irradiation may have influenced the anthocyanin concentration in apples under early heating cultivation in a greenhouse.

\subsection{LED irradiation and antioxidant activity}

The superoxide anion radical scavenging activity in the skin of apple fruit is expressed as the $\mathrm{EC}_{50}$ value (figure 4). Low $\mathrm{EC}_{50}$ values indicate high antioxidant activity. The apples treated with red or blue LED irradiation had lower $\mathrm{EC}_{50}$ values than the untreated controls at 130 and 142 DAFB.

Apple skin has high concentrations of polyphenols that contribute to antioxidant activities [37]. The antioxidant potential of apples depends on the concentration and composition of phenolics, which are influenced by environmental factors $[5,38]$. Supplementation with blue LED light stimulated anthocyanin and phenolic concentrations in leaf lettuce (Lactuca sativa L.) [39]. Red LED irradiation can increase $\beta$-carotene and antioxidant activity in the leaves of pea seedlings (Pisum sativum L.) [33]. The present results showed that the apple fruits irradiated with red or blue LED light had low $\mathrm{EC}_{50}$ values compared with the untreated controls. The lower $\mathrm{EC}_{50}$ values in red or blue LED-treated skin may depend on the accumulation of polyphenols such as anthocyanins.

\section{Conclusion}

The anthocyanin concentrations in red LED-treated apples were increased compared with the blue LED-treated apples and untreated controls. The relative expression of MdMYB10 and MdUFGT genes was highest in the skin of apples treated with red LED. The skin of apple fruits treated with red or blue LED light showed significantly low $\mathrm{EC}_{50}$ values. Red LED irradiation may increase anthocyanin synthesis and antioxidant activity in apple skin under early heating cultivation in a greenhouse.

\section{References}

[1] Boyer J., Liu R.H., Apple phytochemicals and their health benefits, Nutr. J. 3 (2004) 1-15.

[2] Koning R.A., Grayson I., Weckbecker C., The effects of bilberries, blackcurrants and their constituent anthocyanins on heart in humans, Agro. Food Ind. Hi-tech 26 (2015) 16-20.

[3] Charepalli V., Reddivari L., Radhakrishnan S., Vadde R., Agarwal R., Vanamala J.K.P., Anthocyanin-containing purplefleshed potatoes suppress colon tumorigenesis via elimination of colon cancer stem cells, J. Nutr. Biochem. 26 (2015) 1641-1649.

[4] Shim S.H., Kim J.M., Choi C.Y. Kim C.Y., Park K.H., Ginkgo biloba and bilberry anthocyanins improve visual function in patients with normal tension glaucoma, J. Med. Food 15 (2012) 818-823.

[5] Lancaster J.E., Regulation of skin color in apples, Crit. Rev. Plant Sci. 10 (192) 487-502.

[6] WinkeI-Shirley B., Flavonoid biosynthesis. A colorful model for genetics, biochemistry, cell biology and biotechnology, Plant Physiol. 126 (2001) 485-493.

[7] Rabinovich A.T., Studies on apple peel color regulation, University of Minnesota, Minnesota, America, Dissertation, 2009, 55 p.

[8] Saure M.C., External control of anthocyanin formation in apple, Sci. Hortic. 42 (1990) 181-218.

[9] Yamasaki H., Uefuji H., Sakihama Y., Bleaching of the red anthocyanin induced by superoxide radical, Arch. Biochem. Biophys. 332 (1996) 183-186.

[10] Stanelonia R.J., Rodriguez-Betilera M.J., Casal J.J., Abscisic acid, high-light and oxidative stress down-regulate a photosynthetic gene via a promoter motif not involved in phytochrome mediated transcriptional regulation, Mol. Plant 1 (2008) 75-83.

[11] Massa G.D., Kim H.H., Wheeler R.M., Mitchell C.A., Plant productivity in response to LED lighting, HortScience 43 (2008) 1951-1956.

[12] Samuoliene G., Sirtautas R., Brazaitytė A., Viršilè A., Duchovskis P., Supplementary red-LED lighting and the changes in phytochemical content of two baby leaf lettuce varieties during three seasons, J. Food Agric. Env. 10 (2012) 701-706.

[13] Chang C.L., Chang K.P., The growth response of leaf lettuce at different stages to multiple wavelength-band light-emitting diode lighting, Sci. Hortic. 179 (2014) 18-84.

[14] Ma G., Zhang L., Kato M., Yamawaki K., Kiriiwa Y., Yahata M., Ikoma Y., Matsumoto H., Effect of the combination on ethylene and red LED light irradiation on carotenoid accumulation and carotenodenic gene expression in the flavedo of citrus fruit, Postharvest Biol. Technol. 99 (2015) 99-104.

[15] Poudel P.R., Kataoka I., Mochoka R., Effect of red- and bluelight emitting diodes on growth and morphogenesis of grapes, Plant Cell Tissue Organ Cult. 92 (2008) 147-153.

[16] Kondo S., Tomiyama H., Rodyoung A., Okawa K., Ohara H., Sugaya S., Terahara N., Hirai N., Abscisic acid metabolism and anthocyanin synthesis in grape skin are affected by light emitting diode (LED) irradiation at night, J. Plant Physiol. 171 (2014) 823-829. 
[17] Kobayashi S., Ishimaru M., Hiraoka K., Honda C., Myb-related genes of the Kyoho grapes (Vitis labruscana) regulate anthocyanin biosynthesis, Planta 215 (2002) 924-933.

[18] Espley R.V., Hellens R.P., Putterill J., Stevenson D.E., Kutty-Amma S., Allan A.C., Red colouration in apple fruit due to the activity of the MYB transcription factor, MdMYB10, Plant J. 49 (2007) 414-427.

[19] Honda C., Besso H., Murai M., Iwanami H., Moriya S., Abe K., Wada M., Moriya-Tanaka Y., Hayama H., Tatsuki M, Effect of temperature on anthocyanin synthesis and ethylene production in the fruit on early- and medium-maturing apple cultivars during ripening stages, HortScience 49 (2014) 1510-1517.

[20] Wang B., He J., Duan C., Yu X., Zhu L., Xie Z., Zhang C., $\mathrm{Xu}$ W., Wang S., Root restriction affects anthocyanin accumulation and composition in berry skin of 'Kyoho' grape (Vitis vinifera L. $\times$ Vitis labrusca L.) during ripening, Sci. Hortic. 137 (2012) 20-28.

[21] Sankat C.K, Maharaj R.P., Postharvest physiology and storage of tropical and subtropical fruits, in: Mitra S. (Eds.), Papaya, CAB International, Wallingford, UK, 1997.

[22] Wang L., Zhang X., Liu Y., Shi X., Wang Y., Zhang C., Zhao Z., The effect of fruit bagging on the color, phenolic compounds and expression of the anthocyanin biosynthetic and regulatory genes on the 'Granny Smith' apples, Eur. Food Res. Technol. 237 (2013) 875-885.

[23] Yamane T., Jeong S.T., Goto-Yamamoto N., Koshita Y., Kobayashi S., Effects of temperature on anthocyanin biosynthesis in grape berry skins. Am. J. Enol. Vitic. 57 (2006) 54-59.

[24] Azuma A., Yakushiji H., Koshita Y., Kobayashi S., Flavonoid biosynthesis-related genes in grape skin are differentially regulated by temperature and light conditions, Planta 236 (2012) 1067-1080.

[25] Takos A.M., Jaffé F.W., Jacob S.R., Robinson S.P., Walker A.R., Light-induced expression of a $M Y B$ gene regulates anthocyanin biosynthesis in red apples, Plant Physiol. 142 (2006) 1216-1232.

[26] Ban Y., Honda C., Bessho H., Pang, X., Moriguchi T., Suppression subtractive hybridization identifies genes induced in response to UV-B irradiation in apple skin: isolation of a putative UDP-glucose 4-epimerase, J. Exp. Bot. 58 (2007) 1825-1834.
[27] Feng F., Li M., Ma F., Cheng L., Phenylpropanoid metabolites and expression of key genes involved in anthocyanin biosynthesis in the shaded peel of apple fruit in response to sun exposure, Plant Physiology and Biochemistry 69 (2013) 54-61.

[28] Zoratti L., Karppinen K., Escobar A.L., Häggman H., Jaakola L., Light-controlled flavonoid biosynthesis in fruits, Front. Plant Sci. 5 (2014) 1-16.

[29] Li Z., Gemma H., Iwahori S., Stimulation of 'Fuji' apple skin color by ethephon and phosphorus-calcium mixed compounds in relation to flavonoid synthesis, Sci. Hortic. 94 (2002) 193-199.

[30] Kamuro Y., Tohyama T., Okabe K., New functional photoselective sheets. Regul. Plant Growth Dev. 38 (2003) 132-138.

[31] Shoji K., Goto E., Hashida S., Goto F., Yoshihara T., Effect of red light and blue light on the anthocyanin accumulation and expression of anthocyanin biosynthesis genes in red-leaf lettuce, J. Sci. High Technol. Agric. 22 (2010) 107-113.

[32] Xu F., Cao S., Shi L., Chen W., Su X., Yang Z., Blue light irradiation affects anthocyanin content and enzyme activities involved in postharvest strawberry fruit, J. Agric. Food Chem. 62 (2014) 4778-4783.

[33] Nito K., Wong C.C., Yates J.R. and Chory, J., Tyrosine phosphorylation regulates the activity of phytochrome photoreceptors, Cell Rep. 3 (2013) 1970-1979.

[34] Zheng Y., Tian L., Liu H., Pan Q., Zhan J., Huang W., Sugar induce anthocyanin accumulation and flavanone 3-hydroxylase expression in grape berries, Plant Growth Regul. 58 (2009) 251-260.

[35] Proctor J.T.A., Color stimulation in attached apples with supplementary light, Can. J. Plant Sci. 54 (1974) 499-503.

[36] Khomdram S.D., Singh P.K., Polyphenolic compounds and free radical scavenging activity in eight Lamiaceae herbs of Manipur, Notulae Scientia Biologicae 3 (2011) 108-113.

[37] Kondo S., Hiraoka K., Kobayashi S., Honda C., Terahara N., Changes in the expression of anthocyanin biosynthesis genes during apple development, J. Am. Soc. Hortic. Sci. 127 (2002) 971-976.

[38] Wu M.C., Hou C.Y., Jiang C.M., Wang Y.T., Wang C.Y., Chen H.H., Chang H.M., A novel approach of LED light radiation improves the antioxidant activity of pea seedlings, Food Chem. 101 (2007) 1753-1758.

[39] Li Q., Kubota C., Effects of supplemental light quality on growth and phytochemicals of baby leaf lettuce, Env. Exp. Bot. 67 (2009) 59-64. 